\title{
https://gmsmicrofungi.org: an online database providing updated information of microfungi in the Greater Mekong Subregion
}

\section{Chaiwan $\mathbf{N}^{1}$, Gomdola $\mathrm{D}^{1}$, Wang $\mathrm{S}^{1}$, Monkai $\mathrm{J}^{1}$, Tibpromma $\mathrm{S}^{2,3,7}$, Doilom $\mathbf{M}^{4,5,6}$, Wanasinghe $\mathrm{DN}^{2,3,7}$, Mortimer $\mathrm{PE}^{3,7}$, Lumyong $\mathrm{S}^{4,5,8}$ and $\mathrm{Hyde}_{\mathrm{KD}}{ }^{1 *}$}

\author{
${ }^{1}$ Center of Excellence in Fungal Research, Mae Fah Luang University, Chiang Rai, 57100, Thailand \\ ${ }^{2}$ East and Central Asia Regional Office, World Agroforestry Centre (ICRAF), Kunming 650201, Yunnan, People's \\ Republic of China \\ ${ }^{3}$ Centre for Mountain Futures (CMF), Kunming Institute of Botany, Kunming 650201, Yunnan, People's Republic of \\ China \\ ${ }^{4}$ Department of Biology, Faculty of Science, Chiang Mai University, Chiang Mai 50200, Thailand \\ ${ }^{5}$ Research Center of Microbial Diversity and Sustainable Utilization, Faculty of Science, Chiang Mai University, \\ Chiang Mai 50200, Thailand \\ ${ }^{6}$ Innovative Institute for Plant Health, Zhongkai University of Agriculture and Engineering, Guangzhou 510225, \\ Guangdong Province, People's Republic of China \\ ${ }^{7}$ Center for Mountain Futures, Kunming Institute of Botany, Chinese Academy of Sciences, Honghe County 654400, \\ Yunnan, China \\ ${ }^{8}$ Academy of Science, The Royal Society of Thailand, Bangkok 10300, Thailand
}

Chaiwan N, Gomdola D, Wang S, Monkai J, Tibpromma S, Doilom M, Wanasinghe DN, Mortimer PE, Lumyong S, Hyde KD 2021 - https://gmsmicrofungi.org: an online database providing updated information of microfungi in the Greater Mekong Subregion. Mycosphere 12(1), 1513-1526, Doi 10.5943/mycosphere/12/1/19

\begin{abstract}
The Greater Mekong Subregion is a biodiversity hotspot including Yunnan Province, China and Thailand. It is home to an extremely large diversity of microfungi. The highly variable climate and vast range of floral diversity facilitates rapid speciation and diversity in microfungi. During the last few decades, microfungi from the Greater Mekong Subregion on different substrates have been published and reclassified, and many new species have been introduced. However, numerous knowledge gaps concerning species diversity and systematics, challenge the current understanding of the fungi in the region. Basic information of microfungi in the Greater Mekong Subregion, such as taxonomic diversity, molecular phylogeny and host-specificity is incomplete, and available data have not been integrated on a specific platform where all data can be easily retrieved. To address this issue, a website: https://gmsmicrofungi.org, focusing on the microfungi reported from the Greater Mekong Subregion has been developed. This website is a portal to comprehensive information on microfungi and updated notes of species reported from the Greater Mekong Subregion, with easily accessible and searchable functions.
\end{abstract}

Key words - Ascomycota - Chinese mycota - fungi website - taxonomy - Thai mycota

\section{Introduction}

Microfungi play crucial roles and are important to natural ecosystems as decomposers that degrade dead organic materials. They are endophytic, pathogenic or saprobic, or they are can be epiphytes and symbionts depending on the environment (Hyde et al. 2014). Microfungi are also key 
organisms in the nutrient cycling process, which drives sustainable ecosystems (Vandenkoornhuyse et al. 2002, Zhang et al. 2017). They are diverse and ubiquitous heterotrophic organisms (Joshi \& Chettri 2019). Mycorrhizal fungi share symbiotic relationships with plants by inhabiting plant roots (Kehri et al. 2018). They are vital for the productivity of farmland by supplying essential nutrients for plant growth (Chen et al. 2018). Saprobic microfungi penetrate substrates and enzymes are released that break down components (Bucher et al. 2004). Owing to the production of various secondary metabolites, microfungi are extremely important to human health and welfare (Jayakumar et al. 2016, Hyde et al. 2019). For example, Penicillium spp. are used to produce betalactam antibiotics, which are used in penicillin's and cephalosporins (Ozcengiz \& Demain 2013). Microfungi are also important in biotechnological applications (Hyde et al. 2019).

In plant pathology, fungal species are responsible for significant economic losses and negative outcomes in agriculture, forestry and natural ecosystems (Jayawardena et al. 2020). Studies of systematics, biology and control of phytopathogenic fungi have not fully clarified lifestyles of pathogenic fungi (Hyde et al. 2014). The diversity of pathogenic fungi leads to a widespread species identification problem. As a part of natural ecosystems, they also play an important role in environments and remain poorly understood.

The current estimated species number of fungi is between 2.2 to 3.8 million (Hawksworth \& Lücking 2017). It is important to establish fungal-host specificity and investigate fungal diversity in poorly studied countries or regions (Chethana et al. 2020a, Hyde et al. 2020a).

The Greater Mekong Subregion is a landscape influenced by the Mekong River, comprising Cambodia, the People's Republic of China (PRC, specifically Yunnan Province and Guangxi Zhuang Autonomous Region), Lao People's Democratic Republic (Lao PDR), Myanmar, Thailand and Vietnam (Asian Development Bank 2012). The Greater Mekong Subregion is a biodiversity hotspot spanning temperate to tropical regions (Li et al. 2018, Estoque et al. 2019) and is home to the world's tropical and evergreen forests forming unique ecosystems with high levels of biodiversity (Smith et al. 2002). Moist and dry mixed deciduous forests have different tree communities at the upper and lower elevations. These forests contain valuable timber: teak (Tectona grandis) as well as the largest mangrove area around the Mekong River estuaries. Forests have been converted to crop plantations in southern Yunnan (China). The establishment of plantations for the production of rubber, coffee, tea, cashew nuts, cacao, coconut, sugarcane, para rubber and palm oil are the primary drivers of forest loss (Stibig et al. 2010, Senwanna et al. 2019, 2020, 2021).

The Greater Mekong Subregion microfungal diversity has been relatively well-studied in Yunnan Province, China and in northern Thailand, whereas other regions lack accurate and comprehensive documentation of fungal diversity. Yunnan Province is geographically circumscribed by the Tibet Autonomous Region to the northwest, Sichuan to the north, Guizhou to the east and the Zhuang Autonomous Region of Guangxi to the southeast. Yunnan shares an international border with Laos and Vietnam at the south and southeast periphery as well as with Myanmar at the west and southwest. Studies into Thailand's fungal diversity have been on the increase since 2015 (Ariyawansa et al. 2015, Liu et al. 2015, Chethana et al. 2020b, Hyde et al. 2020d). Only about 6,000 species descriptions have been reported from Yunnan Province in China of which around 3,000 species were higher fungi (Feng \& Yang 2018), accounting for approximately $40 \%$ of all fungal taxa in China (Yang 2005). In northern Thailand, Hyde et al. (2018) reported that the percentage of new microfungi is up to $96 \%$, showing a high diversity.

Many studies of microfungi have been carried out in the Greater Mekong Subregion, such as the diversity of terrestrial fungi on woody and leaf litter (Kodsueb et al. 2008, Boonmee et al. 2011, Promputtha et al. 2017), freshwater fungi on submerged wood (Luo et al. 2018a, b, Dong et al. 2020) and microfungi on various hosts - such as bamboo, Chromolaena odorata, Clematis spp., Dracaena spp., Magnolia spp., palms, Pandanus spp., Rhododendron spp. and Tectona grandis (teak) (Table 1). Karst fungi and cave fungi have also been studied in recent years (Zhang et al. 2020). 
Table 1 Lists of microfungi published on various hosts and substrates in the Greater Mekong Subregion during the past decade.

\begin{tabular}{|c|c|c|}
\hline Host & Location & References \\
\hline Bamboo & Thailand, Yunnan (China) & Phookamsak et al. (2015), Dai et al. (2017) \\
\hline Camellia spp. & Yunnan (China) & Abeywickrama et al. (2020) \\
\hline Chromolaena odorata & Thailand & Mapook et al. (2020) \\
\hline Clematis spp. & Thailand & Phukhamsakda et al. (2020) \\
\hline Dead Woody Twigs & Yunnan (China) & Mortimer et al. (2021) \\
\hline Decaying leaves & Vietnam & Yen et al. (2021) \\
\hline Dracaena spp. & Thailand & Chaiwan et al. (2020a, b) \\
\hline Eucalyptus plantations & Yunnan (China) & Li et al. (2020) \\
\hline Insect fungi & Thailand & Xiao et al. (2019) \\
\hline $\begin{array}{l}\text { Leaves of plants with } \\
\text { leaf spots or other lesions }\end{array}$ & Laos & Phengsintham et al. (2010a, b, 2013) \\
\hline Magnolia spp. & Yunnan (China) & Wanasinghe et al. (2020) \\
\hline Grasses & Thailand & $\begin{array}{l}\text { Goonasekara et al. (2018), Hyde et al. (2018), } \\
\text { Karunarathna et al. (2019, 2020), Brahmanage et } \\
\text { al. (2020), Wanasinghe et al. (2020) }\end{array}$ \\
\hline Musaceae & Thailand & Samarakoon et al. (2020) \\
\hline Palms & Thailand & $\begin{array}{l}\text { Wanasinghe et al. (2018a), Chen et al. (2020), } \\
\text { Konta et al. (2020) }\end{array}$ \\
\hline Pandanus spp. & Thailand, Yunnan (China) & Tibpromma et al. $(2016,2018)$ \\
\hline Peanut kernels & Myanmar & Chein et al. (2019) \\
\hline Rhizophora spp. & Thailand & $\begin{array}{l}\text { Norphanphoun et al. (2019), Dayarathne et al. } \\
(2020)\end{array}$ \\
\hline Rhododendron spp. & Yunnan (China) & $\begin{array}{l}\text { Tian et al. (2011), Li et al. (2016), Thiyagaraja et } \\
\text { al. (2020) }\end{array}$ \\
\hline Rosa spp. & Yunnan (China) & Wanasinghe et al. (2018b) \\
\hline Submerged wood & Thailand, Yunnan (China) & Luo et al. (2019), Dong et al. (2020) \\
\hline Tectona grandis (teak) & Thailand & Doilom et al. (2017) \\
\hline Unidentified leaves & Myanmar & Nozawa et al. (2018) \\
\hline
\end{tabular}

However, basic information of microfungi, such as taxonomic diversity, molecular phylogeny, ecological roles, biogeographic distributions and host-specificity are either poorly understood or missing in other countries in this region, compared to Thailand and Yunnan, China. To address this issue, it is important to develop a database to collate all of the scattered information. An online platform of microfungi in the Greater Mekong Subregion will enrich our current knowledge and provide an up-to-date record.

\section{Why we need an online database for microfungi in the Greater Mekong Subregion}

The Greater Mekong Subregion is a region with a potentially high number of undiscovered fungal species. Studies continue to reveal novel taxa in the Greater Mekong Subregion at an remarkable pace (Tibpromma et al. 2016, 2018, Doilom et al. 2017, Hyde et al. 2018, 2020b, Phookamsak et al. 2019, Dong et al. 2020, Mapook et al. 2020, Phukhamsakda et al. 2020). In the case of microfungi, the numbers are likely to be even higher. This is because there are numerous cryptic species as well as undiscovered genera. The current taxonomic classification and systematics of microfungi in the Greater Mekong Subregion continue to lack up-to-date information, while many published data remain unintegrated. Therefore, it is important to collate all information in to a comprehensive, continuously updated database. The Greater Mekong Subregion website (gmsmicrofungi.org) has accordingly been configured to document all species of microfungi reported from this region. The database provides an updated list of microfungi in the Greater Mekong Subregion, specifically reporting relationships with host plants. The Greater Mekong Subregion website provides notes on each taxon reported from the Greater Mekong Subregion region, keeping abreast of current research. The Greater Mekong Subregion database, so 
far, mainly incorporates microfungi reported from northern Thailand and Yunnan Province, China. The database will be further expanded to other parts of the Greater Mekong Subregion as new data becomes available. Data collection will provide a better understanding of microfungal ecology and distribution in different hosts and habitats in the Greater Mekong Subregion, and the website will serve as a directory for fungal biodiversity and host-specificity in the Greater Mekong Subregion.

\section{What is on the website content?}

The Greater Mekong Subregion website provides notes on each microfungus taxon reported from this region based on morphological and molecular data, keeping abreast of current research. Description and notes concerning placement and status are provided for each species. The entry represents published data of microfungi species reported from Greater Mekong Subregion, including species name, Faces of fungi number, Index Fungorum/MycoBank number, description, habitat, distribution, material examined, notes, photographic plates, culture, sequence availability and reference (Fig. 1).

We will further expand and include the synopses and keys to genera and species as well as other important data, wherever available through links from other related webpages including "Faces of Fungi" (Jayasiri et al. 2015; http://www.facesoffungi.org); "One Stop Shop" (Jayawardena et al. 2019) (https://onestopshopfungi.org); "Marine fungi" (Jones et al. 2019) (http://marinefungi.org); "Freshwater fungi" (Calabon et al. 2020) (http://freshwaterfungi.org); "Sordariomycetes" (Bundhun et al. 2020) (https://sordariomycetes.org); "Fungal Genera" (Monkai et al. 2020) (https://www.fungalgenera.org) and "Outline of Fungi" (Wijayawardene et al. 2020) (https://www.outlineoffungi.org).

\section{Construction}

All microfungi in the Greater Mekong Subregion area will be incorporated into the database according to the most recent classifications of Ascomycota (Wijayawardene et al. 2020). The database will be updated regularly as new information becomes available. Outlines, detailed descriptions and notes of each entry on the website will be carefully verified by the curators (Table 2).

Table 2 List of expert curators with their contact information.

\begin{tabular}{|c|c|c|c|}
\hline Position & Name & Address & Contact information \\
\hline \multirow[t]{2}{*}{$\begin{array}{l}\text { Head } \\
\text { Curators }\end{array}$} & Kevin D. Hyde & $\begin{array}{l}\text { Center of Excellence in Fungal Research, } \\
\text { School of Science Mae Fah Luang } \\
\text { University, Chiang Rai, Thailand } 57100\end{array}$ & kdhyde3@gmail.com \\
\hline & Peter E. Mortimer & $\begin{array}{l}\text { Centre for Mountain Futures (CMF), } \\
\text { Kunming Institute of Botany, Kunming } \\
650201 \text {, Yunnan, People's Republic of } \\
\text { China }\end{array}$ & petermortimer@mac.com \\
\hline \multirow[t]{2}{*}{$\begin{array}{l}\text { Managing } \\
\text { curators }\end{array}$} & Dhanushka N. Wanasinghe & $\begin{array}{l}\text { Centre for Mountain Futures (CMF), } \\
\text { Kunming Institute of Botany, Kunming } \\
\text { 650201, Yunnan, People's Republic of } \\
\text { China }\end{array}$ & dnadeeshan@gmail.com \\
\hline & Napalai Chaiwan & $\begin{array}{l}\text { Center of Excellence in Fungal Research, } \\
\text { School of Science, Mae Fah Luang } \\
\text { University, Chiang Rai, Thailand } 57100\end{array}$ & baimai_napalai@hotmail.com \\
\hline \multirow[t]{2}{*}{ Curators } & Jutamart Monkai & $\begin{array}{l}\text { Center of Excellence in Fungal Research, } \\
\text { School of Science, Mae Fah Luang } \\
\text { University, Chiang Rai, Thailand } 57100\end{array}$ & mjutamart@gmail.com \\
\hline & Rungtiwa Phookamsak & $\begin{array}{l}\text { Centre for Mountain Futures (CMF), } \\
\text { Kunming Institute of Botany, Kunming } \\
650201 \text {, Yunnan, People's Republic of } \\
\text { China }\end{array}$ & rphookamsak@outlook.com \\
\hline
\end{tabular}


Table 2 Continued.

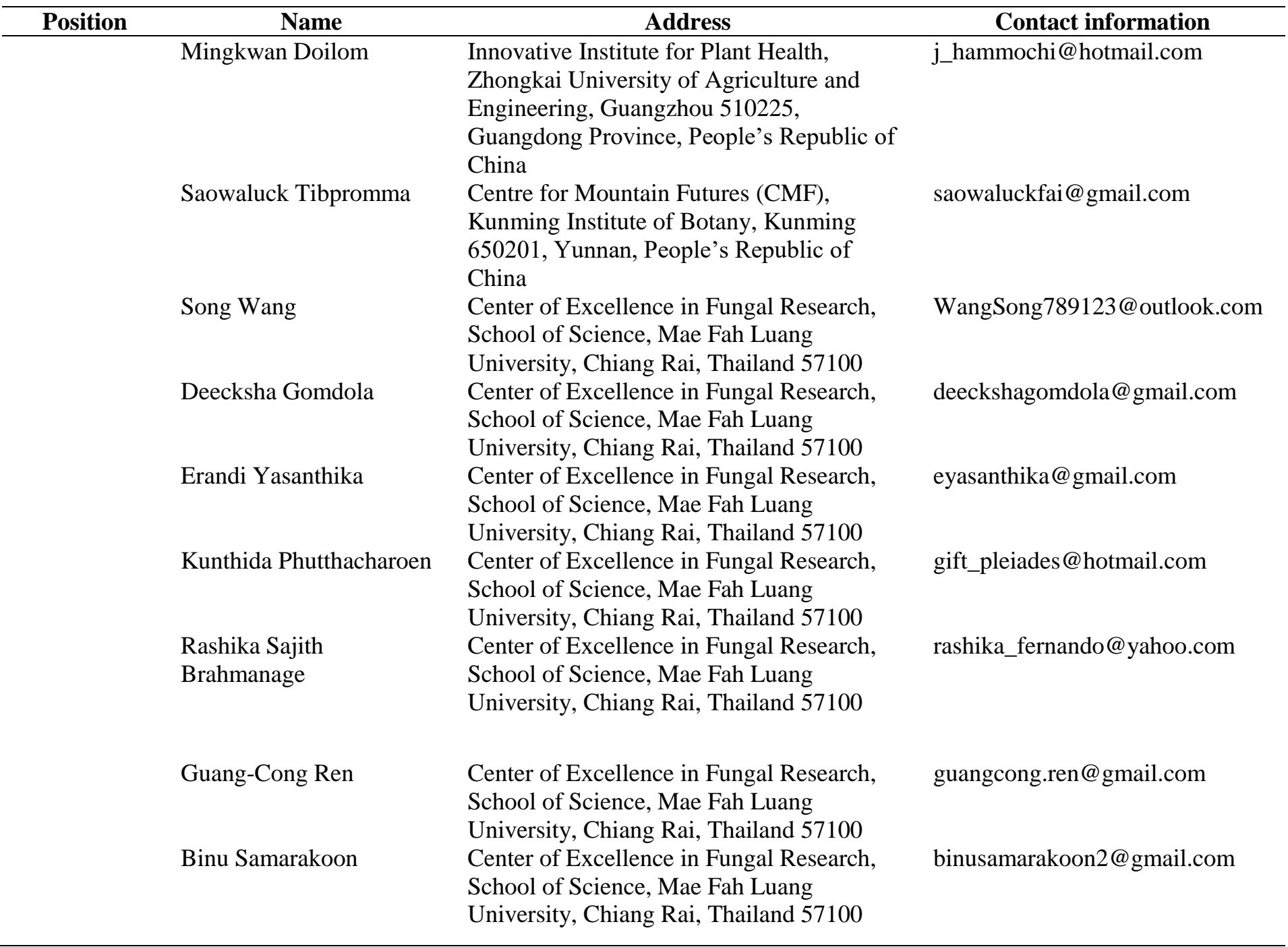

\section{Database interface and visualization}

The website gmsmicrofungi.org is an online platform that compiles published information based on the classification and taxonomy of microfungi in the Greater Mekong Subregion. The website's interface is simple and user-friendly (Fig. 1). The heading provides the nine features and functions of the website. The right side of the webpage lists all recent uploaded genera and species. The search toolbar can be found above 'Recent Genus' section of the webpage. To find the genus or taxon of interest, input relevant information in the search box and a pop-up window will suggest the target fungi, including its taxonomic level (Fig. 2). Clicking on the species name will direct you to the description, notes, photographic plates and phylogenetic tree of the microfungi in Greater Mekong Subregion (Fig. 3). The references used in the description and notes are linked to the original source to obtain information about the species

The nine different features and functions in the uppermost part as following:

1) Home page provides the ultimate goals of the webpage, the general information of the website (The menu of the functions including the search toolbar show Home, Host/substrate, Archives, Curators, History, References, News, Contact) and an overview of the Greater Mekong Subregion microfungi. Objectives of launching the website are also provided (Fig. 1) and also the reference of this webpage are show if user using the document of this website. The right side show the recent genus and recent species updated from the webpage.

2) Bottom view of the homepage (Fig. 2). This information shows contact details and supporting scholars. 
3) The Host/Substrate tab when user click to this toolbar the function will provide the data about microfungi species. This tab lists all microfungi that have been reported from Greater Mekong Subregion by fungal classification range (Fig. 3).

4) The Archive tab is Greater Mekong Subregion microfungi with the outline of the orders and families of Greater Mekong Subregion microfungi (Fig. 4). When the user opens the "Archives", the list of orders related to Greater Mekong Subregion microfungi can be visualized. By clicking on a relevant order, the link will navigate to "Read more about the order" or related family list of the order. Inside families, the list of associated genera and species are available.

5) Search box (right side), searching species name such as Phaeoacremonium italicum and click "Go" to reveal the details about the species (Fig. 5). The information will show the name of microfungi, the Index Fungorum number and Facesoffungi number. The description with illustration of that microfungi, Culture characteristics, Habitat, known hosts or distribution, Material examined, GenBank Accession Number, Notes and reference of the data are also provided.

6) The Curators section provides the contact information and affiliated institutions of website curators (Fig. 6).

7) The History tab shows a short historical background of Greater Mekong Subregion microfungi, ascomycetes and host list of collection.

8) The References tab is a compilation of all published work (e.g., books, reviews, monographs and articles) and other information related to Greater Mekong Subregion microfungi are provided under this heading.

9) All activities and news related to mycology are shown in the news tab. Contact to the Home page. The 'Contact' section provides contact details for the website and allows users to address any comments and suggestions.

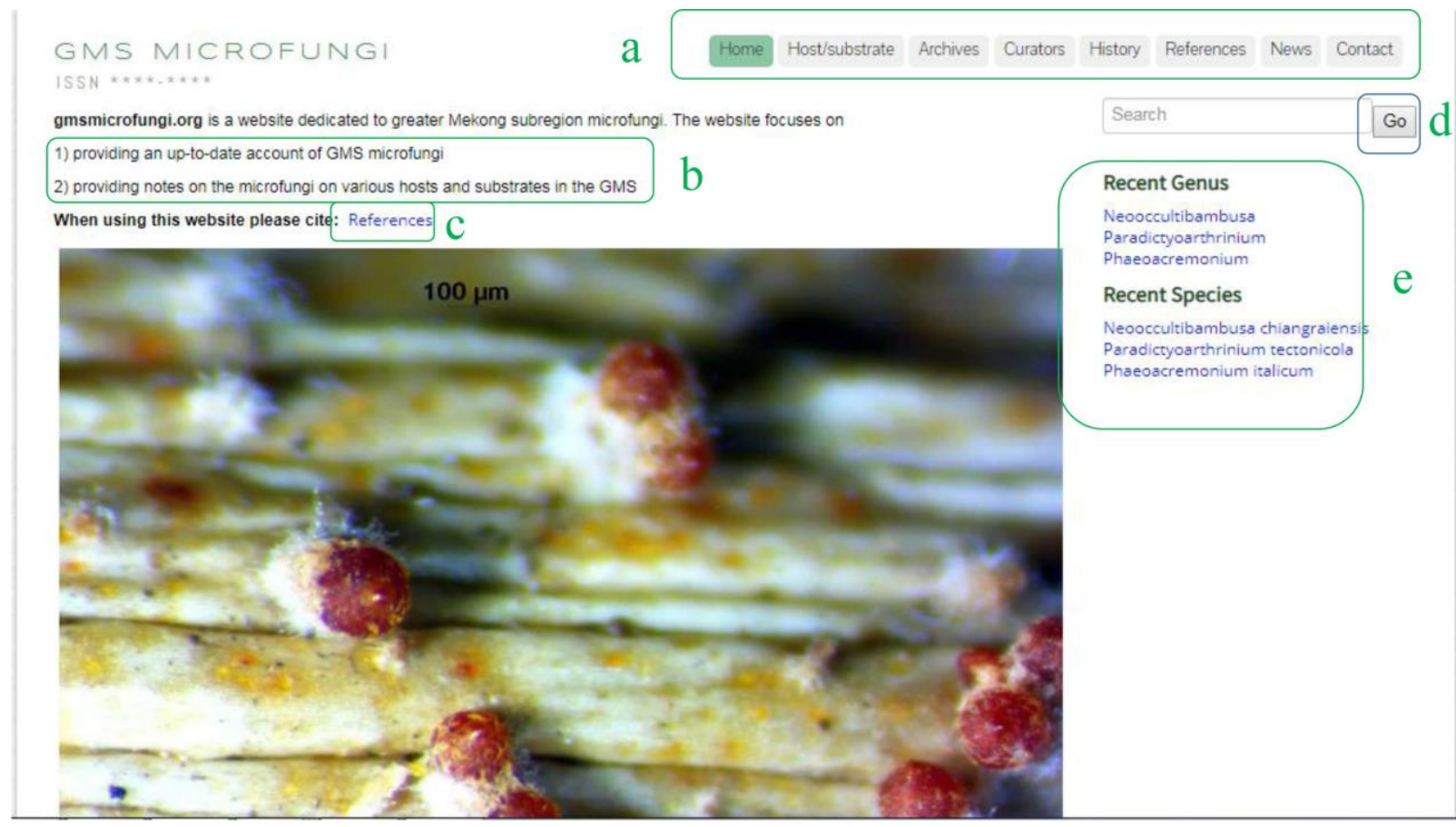

Figure 1 - The homepage view of Greater Mekong Subregion microfungi containing a photo slideshow, with Greater Mekong Subregion microfungi information, and different features and functions including the search toolbar and recent uploaded data. a Headers. b Objectives of the webpage. c Citation of the webpage. $d$ Search box. e Recently updated news, recent genera and species. 


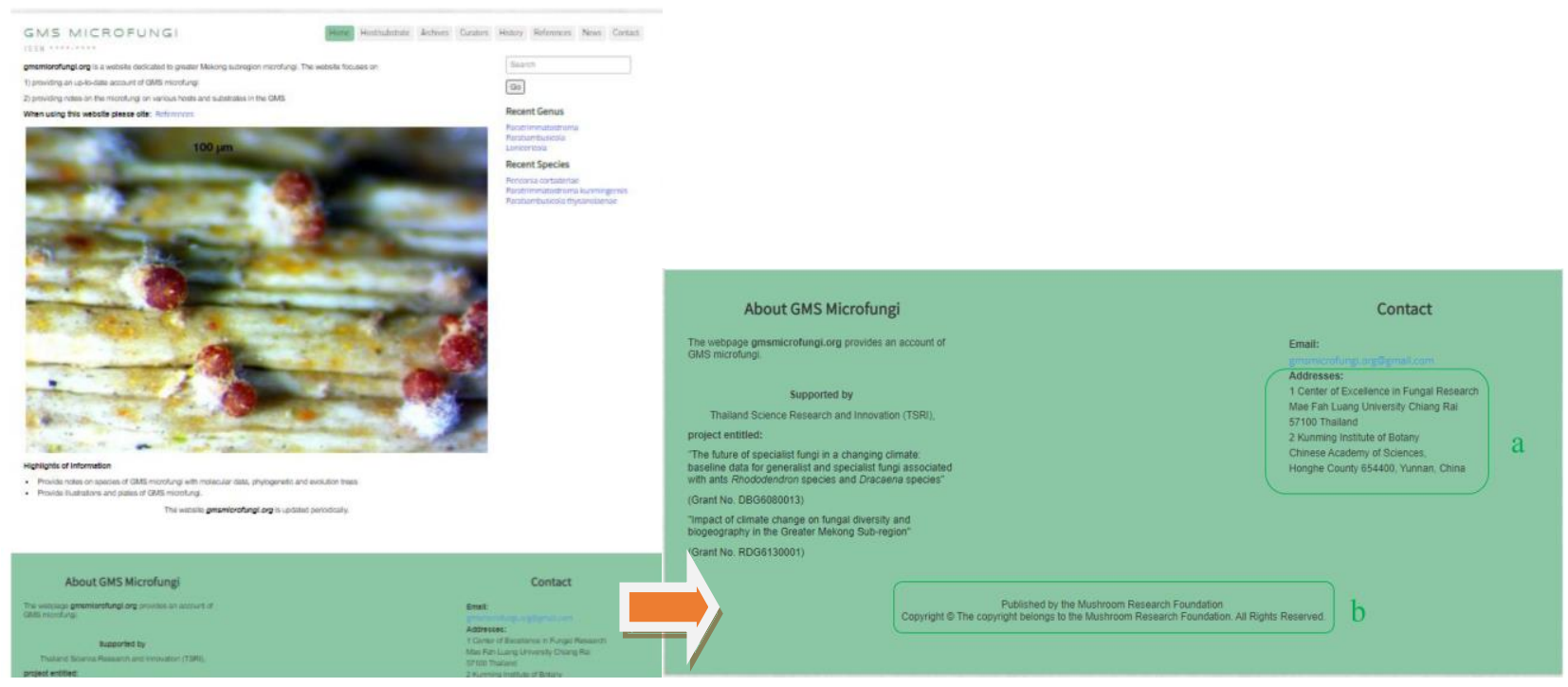

Figure 2 - Go to the bottom of the page. Bottom view of the homepage. a Contact details. b Publisher and copyright information.

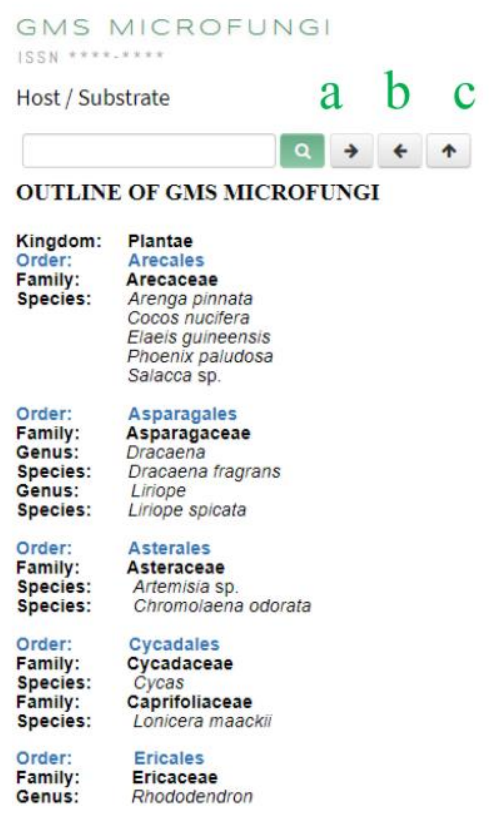

Home Hostsubstrate Archives Curators History References News Contact

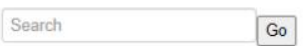

Recent Genus

Neooccultibambusa

Paradictyoarthrinium

Recent Species

Neooccultibambusa chiangraiensis

Paradictyoarthrinium tectonicola

Phaeoscremonium italicum

$\begin{array}{ll}\text { Order: } & \text { Asparagales } \\ \text { Family: } & \text { Asparagaceae } \\ \text { Genus: } & \text { Dracaena } \\ \text { Species: } & \text { Dracaena fragrans } \\ \text { Genus: } & \text { Liriope } \\ \text { Species: } & \text { Liriope spicata } \\ \text { Order: } & \text { Asterales } \\ \text { Family: } & \text { Asteraceae } \\ \text { Species: } & \text { Artemisia sp. } \\ \text { Species: } & \text { Chromolaena odorata } \\ \text { Order: } & \text { Cycadales } \\ \text { Family: } & \text { Cycadaceae } \\ \text { Species: } & \text { Cycas } \\ \text { Family: } & \text { Caprifoliaceae } \\ \text { Species: } & \text { Lonicera maackil } \\ \text { Order: } & \text { Ericales } \\ \text { Family: } & \text { Ericaceae } \\ \text { Genus: } & \text { Rhododendron }\end{array}$

Figure 3 - The section host/substrate of the webpage. a Find next. b Find previous. c Back to top. 


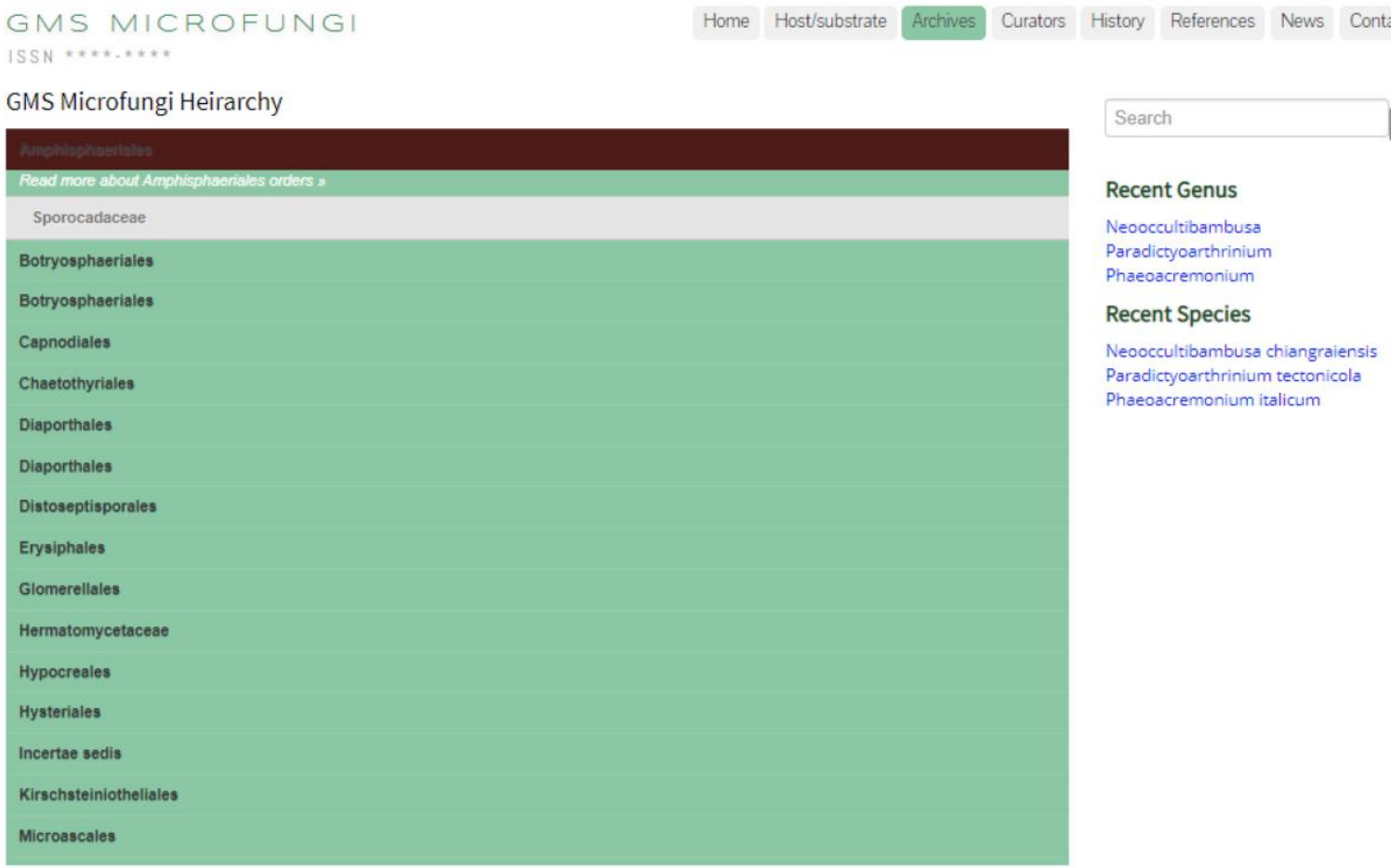

Figure 4 - The Archive tab with the outline of the orders and families of Greater Mekong Subregion microfungi.

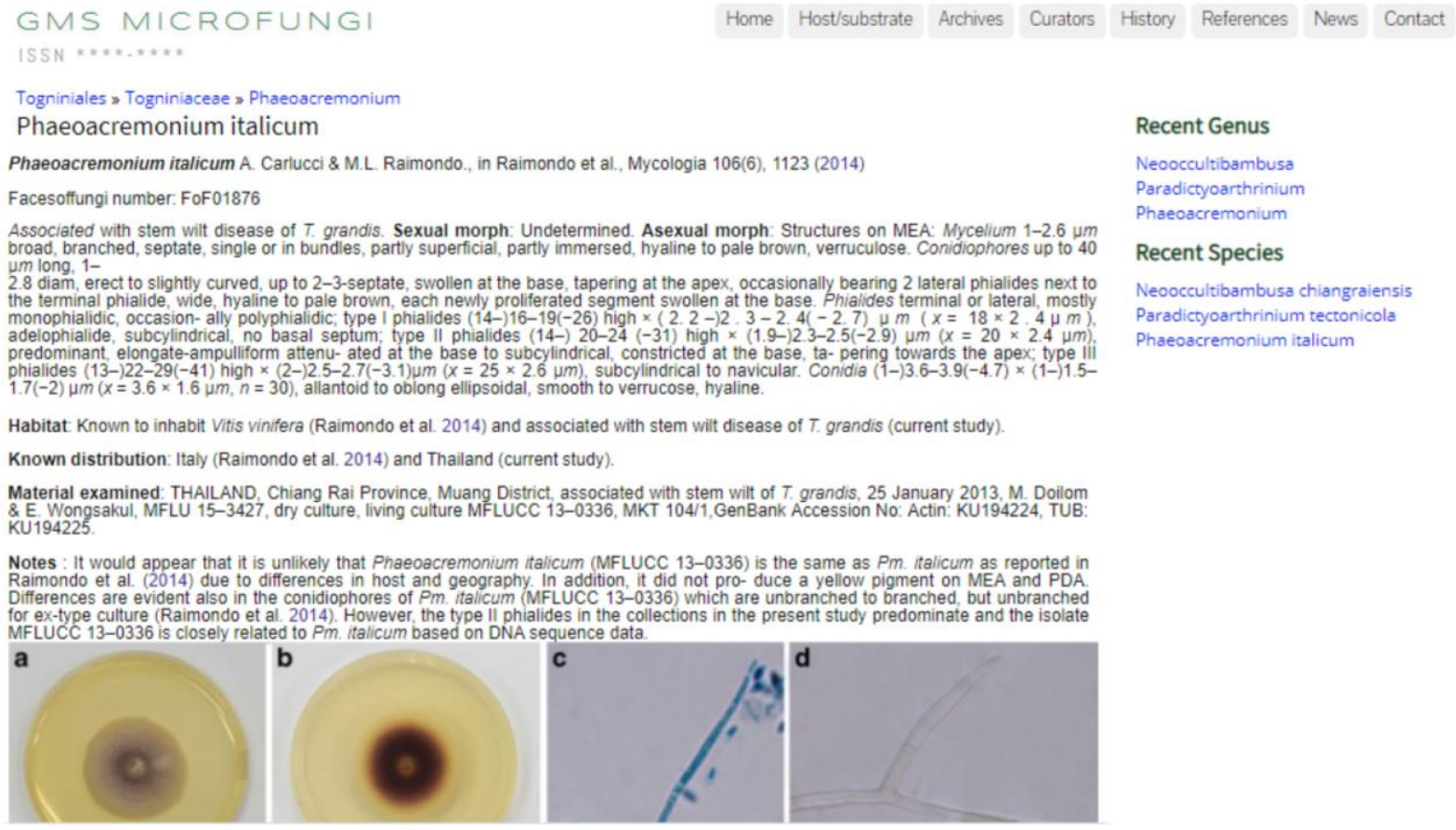

Figure 5 - Clicking a species name such as Phaeoacremonium italicum reveals detailed description. 

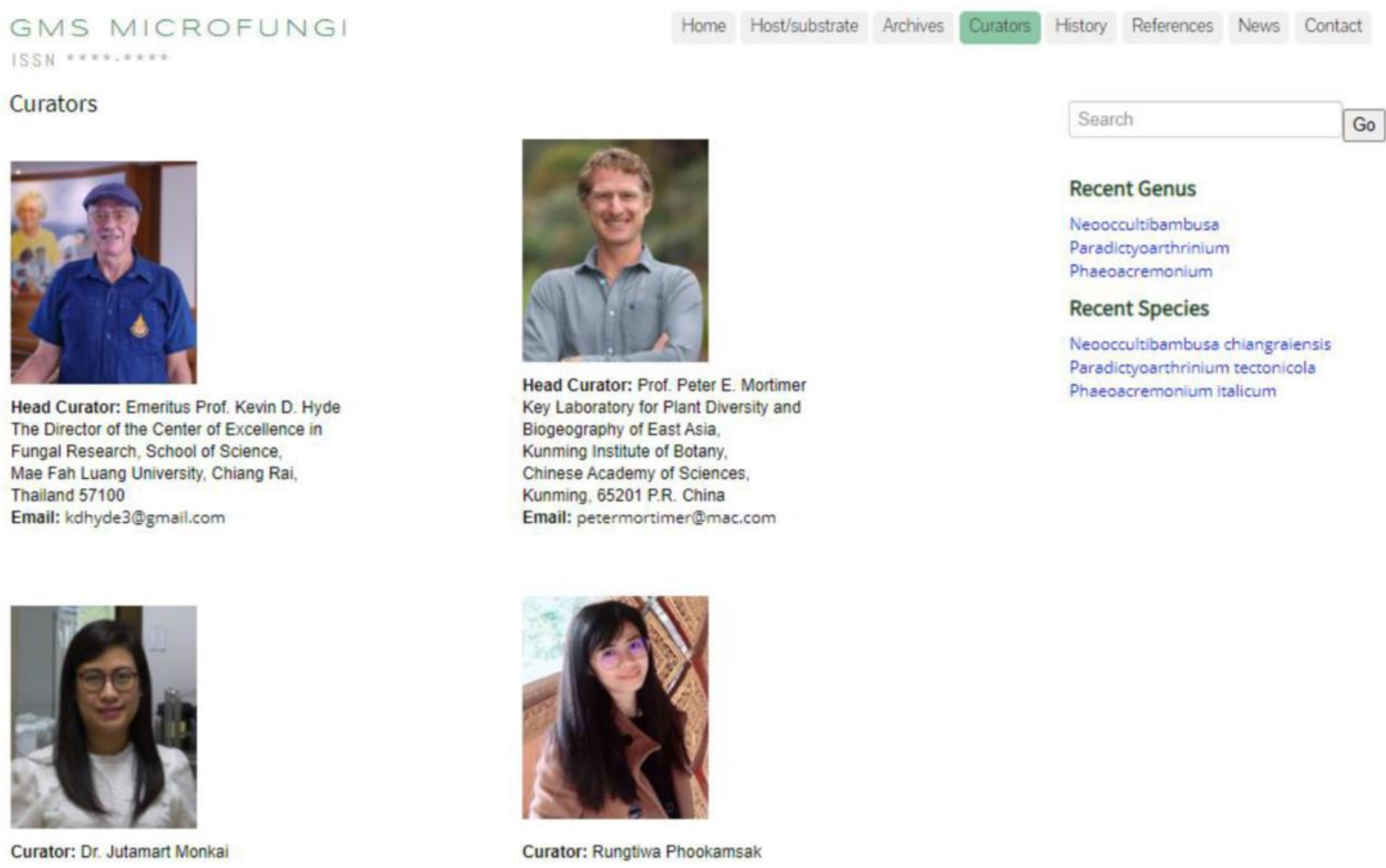

Figure 6 - Website curator information.

\section{Discussion}

Taxonomy links various databases that store information on different organisms. Several global fungal nomenclatural and taxonomic databases can be sourced to find the information about distribution of fungi. While knowledge on fungi and their hosts in tropical Southeast Asia is poor, this database will enrich our knowledge of fungi in Greater Mekong Subregion especially in Yunnan Province (China) and Thailand. The website provides basic information for mycologists to understand fungal distribution that can be exploited further.

The Greater Mekong Subregion is an ideal location to conduct diverse research on microfungal occurrences on specific areas/hosts. Yunnan Province of China and Thailand have tropical and subtropical climates that are favorable for fungal growth and reproduction. These areas are reported having a rich fungal diversity. More than 700 new fungal species have been described in Thailand (Hyde et al. 2018, 2020a, b, c). The idea of the webpage is to gather all this scattered published information in to one user-friendly platform.

The Greater Mekong Subregion microfungi website provides fungal classification information, host specific fungi and other related useful data in the Greater Mekong Subregion, which will enhance current understanding and ultimately enable mycologists to gain better and updated insights into the current fungal diversity in the Greater Mekong Subregion. In addition, the database also allows access to comprehensive data including descriptions of fungi, locations and specific plant-host information of fungi. This is a user-friendly database providing an up-to-date account of Greater Mekong Subregion microfungi and notes of microfungi on various hosts and substrates. The information includes Ascomycota and Eurotiomycetes (comprise four main classes Chaetothyriomycetidae, Dothideomycetes, Leotiomycetes and Sordariomycetes) in various hosts and substrates in the Greater Mekong Subregion. The webpage is managed by 12 experienced curators who upload and update information of fungi in the Greater Mekong Subregion. The present paper introduces the Greater Mekong Subregion microfungi database and provides classification and identification of the main fungal groups in the Greater Mekong Subregion. The presented data are reported from the Yunnan Province in China and Thailand. 


\section{Acknowledgements}

This work was financed by the Mushroom Research Foundation (MRF), Thailand. Napalai Chaiwan is grateful to the Thailand Research Fund (PHD60K0147). Kevin D. Hyde thanks Chiang Mai University for the award of Visiting Professor. Kevin D. Hyde thanks the grants Thailand Science Research and Innovation (TSRI), project entitled: 1 the future of specialist fungi in a changing climate: baseline data for generalist and specialist fungi associated with ants, Rhododendron species and Dracaena species (Grant number: DBG6080013) and 2. The climate changes grant: Impact of climate change on fungal diversity and biogeography in the Greater Mekong Subregion (Grant number: RDG613001). Dhanushka Wanasinghe would like to thank the CAS President's International Fellowship Initiative (number 2019PC0008), the 64th batch of China Postdoctoral Science Foundation (grant no. 2018M643549), Postdoctoral Fund from Human Resources and Social Security Bureau of Yunnan Province. Saowaluck Tibpromma would like to thanks the International Postdoctoral Exchange Fellowship Program (number Y9180822S1), CAS President's International Fellowship Initiative (PIFI) (number 2020PC0009), China Post doctoral Science Foundation, and the Yunnan Human Resources and Social Security Department Foundation for funding her postdoctoral research. Mingkwan Doilom and Saisamorn Lumyong thanks Chiang Mai University for their partial support of this research.

\section{References}

Abeywickrama PD, Wanasinghe DN, Karunarathna SC, Jayawardena RS et al. 2020 - A new host report of Diaporthe manihotia (Diaporthales, Ascomycota) from Camellia sp. in Yunnan province, China. Asian Journal of Mycology 3, 295-306.

Ariyawansa HA, Hyde KD, Jayasiri SC, Buyck B et al. 2015 - Fungal diversity notes 111-252 taxonomic and phylogenetic contributions to fungal taxa. Fungal Diversity 75, 27-274.

Asian Development Bank. 2012 - Greater Mekong Subregion Atlas of the Environment $2^{\text {nd }}$ Edition. Manila, Philippines.

Brahmanage RS, Dayarathne MC, Wanasinghe DN, Thambugala KM et al. 2020 - Taxonomic novelties of saprobic Pleosporales from selected dicotyledons and grasses. Mycosphere 11, 2481-2541.

Boonmee S, Zhang Y, Chomnunti P, Chukeatirote E et al. 2011 - Revision of lignicolous Tubeufiaceae based on morphological reexamination and phylogenetic analysis. Fungal Diversity 51, 63-102.

Bucher VVC, Hyde KD, Pointing SB, Reddy CA. 2004 - Production of wood decay enzymes, mass loss and lignin solubilization in wood by marine ascomycetes and their anamorphs. Fungal Diversity $15,1-14$.

Bundhun D, Maharachchikumbura SSN, Jeewon R, Senanayake IC et al. 2020 https://sordariomycetes.org/, a platform for the identification, ranking and classification of taxa within Sordariomycetes. Asian Journal of Mycology 3, 13-21.

Calabon MS, Hyde KD, Jones EBG, Chandrasiri S et al. 2020 - www.freshwaterfungi.org, an online platform for the taxonomic classification of freshwater fungi. Asian Journal of Mycology 3, 419-445.

Chen M, Arato M, Borghi L, Nouri E et al. 2018 - Beneficial services of arbuscular mycorrhizal fungi - From ecology to application. Frontiers in Plant Science 9, 1-14.

Chen YJ, Jayawardena RS, Bhunjun CS, Harishchanra DL et al. 2020 - Pseudocercospora dypsidis sp. nov. (Mycosphaerellaceae) on Dypsis lutescens leaves in Thailand. Phytotaxa 474, 218 234.

Chaiwan N, Maharachchikumbura SSN, Wanasinghe DN, Doilom M et al. 2020a - First sexual morph record of Sarcopodium vanilla. Mycotaxon 134, 707-717.

Chaiwan N, Wanasinghe DN, Mapook A, Jayawardena RS et al. 2020b - Novel species of Pestalotiopsis fungi on Dracaena from Thailand. Mycology 11, 306-315. 
Chein SH, Sadiq MB, Datta A, Anal AK. 2019 - Prevalence and identification of Aspergillus and Penicillium species isolated from peanut kernels in central Myanmar. Journal of Food Safety 39, e12686.

Chethana KWT, Jayawardena RS, Hyde KD. 2020a - Hurdles in fungal taxonomy: effectiveness of recent methods in discriminating taxa. Megataxa 1, 114-122.

Chethana KWT, Niranjan M, Dong W, Samarakoon MC et al. 2020b - AJOM new records and collections of fungi: 101-150. Asian Journal of Mycology 4, 113-260.

Doilom M, Dissanayake AJ, Wanasinghe DN, Boonmee S et al. 2017 - Microfungi on Tectona grandis (teak) in northern Thailand. Fungal Diversity 82, 107-182.

Dai DQ, Phookamsak R, Wijayawardene NN, Li WJ et al. 2017 - Bambusicolous fungi. Fungal Diversity $82,1-105$.

Dayarathne MC, Jones EBG, Maharachchikumbura SSN, Devadatha B et al. 2020 - Morphomolecular characterization of microfungi associated with marine based habitats. Mycosphere $11,1-188$.

Dong W, Wang B, Hyde KD, McKenzie EHC et al. 2020 - Freshwater Dothideomycetes. Fungal Diversity 105, 319-575.

Estoque RC, Ooba M, Avitabile V, Hijioka Y et al. 2019 - The future of Southeast Asia's forests. Nature Communication 10, 1-12.

Feng B, Yang Z. 2018 - Studies on diversity of higher fungi in Yunnan, southwestern China: A review. Plant Diversity 40, 165-171.

Goonasekara ID, Jayawardene RS, Saichana N, Hyde KD et al. 2018 - Checklist of microfungi on grasses in Thailand (excluding bambusicolous fungi). Asian Journal of Mycology 1, 88-105.

Hawksworth DL, Lücking R. 2017 - Fungal diversity revisited: 2.2 to 3.8 million species. Microbiology Spectrum 5, 79-95.

Hyde KD, Nilsson RH, Alias SA, Ariyawansa HA et al. 2014 - One stop shop: backbones trees for important phytopathogenic genera: I (2014). Fungal Diversity 67, 1-105.

Hyde KD, Norphanphoun C, Chen J, Dissanayake AJ et al. 2018 - Thailand's amazing diversity: up to $96 \%$ of fungi in northern Thailand may be novel. Fungal Diversity 93, 215-239.

Hyde KD, Jeewon R, Chen YJ, Bhunjun CS et al. 2020a - The numbers of fungi: is the descriptive curve flattening?. Fungal Diversity 103, 219-271.

Hyde KD, Dong Y, Phookamsak R, Jeewon R et al. 2020b - Fungal diversity notes 1151-1276: taxonomic and phylogenetic contributions on genera and species of fungal taxa. Fungal Diversity 100, 5-277.

Hyde KD, Chethana KWT, Jayawardena RS, Luangharn T et al. 2020c - The rise of mycology in Asia. ScienceAsia 46S, 1-11.

Hyde KD, de Silva NI, Jeewon R, Bhat DJ et al. 2020d - AJOM new records and collections of fungi: 1-100. Asian Journal of Mycology 3, 22-294.

Jayakumar K, Babu PG, Theja CP, Kumari SG et al. 2016 - Biomedical potentials of Talaromyces tratensis-A new endolichenic fungi associated with high altitude crustose lichen Lecanora sp. Research Journal of Pharmaceutical Biological \& Chemical Sciences 7, 1412-1419.

Jayasiri SC, Hyde KD, Ariyawansa HA, Bhat DJ et al. 2015 - The Faces of Fungi database: fungal names linked with morphology, phylogeny and human impacts. Fungal Diversity 74, 3-18.

Jayawardena RS, McKenzie EHC, Chen YJ, Phillips AJL et al. 2019 https://onestopshopfungi.org/, a webpage to enhance identification of phytopathogenic genera. Asian Journal of Mycology 2, 281-286.

Jayawardena RS, Hyde KD, Chen YJ, Papp V et al. 2020 - One stop shop IV: taxonomic update with molecular phylogeny for important phytopathogenic genera: 76-100. Fungal Diversity 103, 87-218.

Jones EBG, Pang KL, Abdel-Wahab MA, Scholz B et al. 2019 - An online resource for marine fungi. Fungal Diversity 96, 347-433.

Joshi SR, Chettri U. 2019 - Fungi in hypogean environment: Bioprospection perspective. In Advancing Frontiers in Mycology \& Mycotechnology, 539-561. 
Karunarathna A, Phookamsak R, Jayawardena RS, Cheewangkoon R. 2019 - The holomorph of Neoroussoella alishanense sp. nov. (Roussoellaceae, Pleosporales) on Pennisetum purpureum (Poaceae). Phytotaxa 406, 218-236.

Karunarathna A, Phookamsak R, Jayawardena RS, Hyde KD et al. 2020 - Kwanghwana miscanthi Karun., C.H. Kuo \& K.D. Hyde, gen. et sp. nov. (Phaeosphaeriaceae, Pleosporales) on Miscanthus floridulus (Labill.) Warb. ex K. Schum. \& Lauterb. (Poaceae). Cryptogamie Mycologie 46,119-132.

Kehri HK, Akhtar O, Zoomi I, Pandey. 2018 - Arbuscular mycorrhizal fungi: Taxonomy and its systematics. International Journal of Life Sciences Research 6, 58-71.

Kodsueb R, McKenzie EHC, Lumyong S, Hyde KD. 2008 - Diversity of saprobic fungi on Magnoliaceae. Fungal Diversity 30, 37-53.

Konta S, Hyde KD, Phookamsak R, Xu JC et al. 2020 - Polyphyletic genera in Xylariaceae (Xylariales): Neoxylaria gen. nov. and Stilbohypoxylon. Mycosphere 11, 2629-2651.

Li J, Phukhamsakda R, Mapook A, Boonmee S et al. 2016 - Seifertia shangrilaensis sp. nov. (Melanommataceae), a new species from Southwest China Phytotaxa 273, 034-042.

Li H, Guo J, Karunarathna SC, Ye L et al. 2018 - Native Forests Have a Higher Diversity of Macrofungi Than Comparable Plantation Forests in the Greater Mekong Subregion. Forests: 9, 402.

Li G, Slippers B, Wingfield MJ, Chen S. 2020 - Variation in Botryosphaeriaceae from Eucalyptus plantations in YunNan Province in southwestern China across a climatic gradient. IMA Fungus 11, 22-71.

Liu JK, Hyde KD, Jones EBG, Ariyawansa HA et al. 2015 - Fungal diversity notes 1-110: taxonomic and phylogenetic contributions to fungal species. Fungal Diversity 72, 1-197.

Luo ZL, Hyde KD, Liu JK, Bhat DJ et al. 2018a - Lignicolous freshwater fungi from China II: Novel Distoseptispora (Distoseptisporaceae) species from northwestern Yunnan Province and a suggested unified method for studying lignicolous freshwater fungi. Mycosphere 9, 444461.

Luo ZL, Hyde KD, Bhat DJ, Jeewon R et al. 2018b - Morphological and molecular taxonomy of novel species Pleurotheciaceae from freshwater habitats in Yunnan, China. Mycological Progress 17, 511-530.

Luo ZL, Hyde KD, Liu JK, Maharachchikumbura SSN et al. 2019 - Freshwater Sordariomycetes. Fungal Diversity 99, 451-660.

Mapook A, Hyde KD, McKenzie EHC, Jones EBG et al. 2020 - Taxonomic and phylogenetic contributions to fungi associated with the invasive weed Chromolaena odorata (Siam weed). Fungal Diversity 101, 1-175.

Monkai J, McKenzie EHC, Phillips AJL, Hongsanan S et al. 2020 - https://fungalgenera.org/: a comprehensive database providing web-based information for all fungal genera. Asian Journal of Mycology 2, 297-304.

Mortimer PE, Jeewon R, Xu JC, Lumyong S et al. 2021 - Morpho-phylo taxonomy of novel dothideomycetous fungi associated with dead woody twigs in Yunnan Province, China. Frontiers in Microbiology 12, 654-683.

Norphanphoun C, Jayawardena RS, Chen Y, Wen TC et al. 2019 - Morphological and phylogenetic characterization of novel pestalotioid species associated with mangroves in Thailand. Mycosphere 10, 531-578.

Nozawa S, Ando K, Phay N, Watanabe K. 2018 - Pseudopestalotiopsis dawaina sp. nov. and Ps. kawthaungina sp. nov.: two new species from Myanmar. Mycological Progress 17, 865-870.

Ozcengiz G, Demain AL. 2013 - Recent advances in the biosynthesis of penicillins, cephalosporins and clavamTs and its regulation. Biotechnology Advances 31, 287-311.

Phengsintham P, Chukeatirote E, Abdelsalam KA, Hyde KD et al. 2010a - Cercospora and allied genera from Laos 2. Current Research in Environmental \& Applied Mycology 3, 34-158.

Phengsintham P, Chukeatirote E, Bahkali AH, Moslem MA et al. 2010b - Cercospora and allied genera from Laos 3. Cryptogamie, Mycologie 31, 305-322. 
Phengsintham P, Chukeatirote E, McKenzie EHC, Hyde KD et al. 2013 - Monograph of Cercosporoid fungi from Laos. Cryptogamie, Mycologie 31, 161-181.

Phookamsak R, Norphanphoun C, Tanaka K, Dai DQ et al. 2015 - Towards a natural classification of Astrosphaeriella-like species; introducing Astrosphaeriellaceae and Pseudoastrosphaeriellaceae fam. nov. and Astrosphaeriellopsis, gen. nov. Fungal Diversity 74, 143-197.

Phookamsak R, Hyde KD, Jeewon R, Bhat DJ et al. 2019 - Fungal diversity notes 929-1035: taxonomic and phylogenetic contributions on genera and species of fungi. Fungal Diversity 95, 1-273.

Phukhamsakda C, McKenzie EHC, Phillips AJL, Jones EBG et al. 2020 - Microfungi associated with Clematis (Ranunculaceae) with an integrated approach to delimiting species boundaries. Fungal diversity 120, 1-203.

Promputtha I, Mckenzie EHC, Tennakoon DS, Lumyong S et al. 2017 - Succession and natural occurrence of saprobic fungi on leaves of Magnolia liliifera in a tropical forest. Cryptogamie Mycologie 38, 213-225.

Samarakoon BC, Phookamsak R, Wanasinghe DN, Chomnunti P et al. 2020 - Taxonomy and phylogenetic appraisal of Spegazzinia musae sp. nov. and S. deightonii (Didymosphaeriaceae, Pleosporales) on Musaceae from Thailand. MycoKeys 70, 19-37.

Senwanna C, Hongsanan S, Phookamsak R, Tibpromma S et al. 2019 - Muyocopron heveae sp. nov. and $M$. dipterocarpi appears to have host-jumped to rubber. Mycological Progress 18, 741-752.

Senwanna C, Hongsanan S, Hyde KD, Cheewangkoon R et al. 2020 - First report of the sexual morph of Pseudofusicoccum adansoniae Pavlic, T.I. Burgess \& M.J. Wingf. on Para Rubber. Cryptogamie Mycologie 41, 133.

Senwanna C, Mapook A, Samarakoon MC, Karunarathna A et al. 2021 - Ascomycetes on Para rubber (Hevea brasiliensis). Mycosphere 12(1), 1230-1408.

Doi 10.5943/mycosphere/12/1/18

Smith J, Molina R, Huso MM, Luoma D et al. 2002 - Species richness, abundance, and composition of hypogeous and epigeous ectomycorrhizal fungal sporocarps in young, rotation-age, and old-growth stands of Douglas-fir (Pseudotsuga menziesii) in the Cascade Range of Oregon, USA. Canadian Journal of Botany 80, 186-204.

Stibig HJ, Achard F, Carboni S, Rasi R et al. 2010 - Change in tropical forest cover of Southeast Asia from 1990 to 2010. Biogeosciences 11, 247-258.

Thiyagaraja V, Hyde KD, Wanasinghe DN, Worthy FR et al. 2020 - Addition to Melanommataceae: a new geographical record of Alpinaria rhododendri from Shangri La, China. Asian Journal of Mycology 3, 335-344.

Tian W, Zhang CQ, Qiao P, Milne R. 2011 - Diversity of culturable ericoid mycorrhizal fungi of Rhododendron decorum in Yunnan, China. Mycologia 103, 703-709.

Tibpromma S, Hyde KD, McKenzie EHC, Bhat DJ et al. 2018 - Fungal diversity notes 840-928: micro-fungi associated with Pandanaceae. Fungal Diversity 93, 1-160.

Tibpromma S, McKenzie EHC, Karunarathna SC, Mortimer PE et al. 2016 - Muyocopron garethjonesii sp. nov. (Muyocopronales, Dothideomycetes) on Pandanus sp. Mycosphere, 7(9), 1480-1489.

Vandenkoornhuyse P, Baldauf SL, Leyval C, Straczek J et al. 2002 - Extensive fungal diversity in plant roots. (Evolution). Science 295, 2051-2052.

Yang ZL. 2005 - Evolutionary genetics of fungal diversity and biogeography of higher fungi in China. Horizon Bioscience, 35-62.

Yen LTH, Yamaguchi K, Hop DV, Tsurumi Y, et al. 2021 - Phylogeny and a new species of Polylobatispora. Mycoscience 62, 176-181.

Wanasinghe DN, Jeewon R, Jones EBG, Boonmee S et al. 2018a - Novel palmicolous taxa within Pleosporales: multigene phylogeny and taxonomic circumscription. Mycological Progress 17, 571-590. 
Wanasinghe DN, Phukhamsakda C, Hyde KD, Jeewon R et al. 2018b - Fungal diversity notes 709839: taxonomic and phylogenetic contributions to fungal taxa with an emphasis on fungi on Rosaceae. Fungal Diversity 89, 1-236.

Wanasinghe DN, Wijayawardene NN, Xu J, Cheewangkoon R et al. 2020 - Taxonomic novelties in Magnolia-associated pleosporalean fungi in the Kunming Botanical Gardens (Yunnan, China). Plos One 15, e0235855.

Wijayawardene NN, Hyde KD, Al-Ani LKT, Tedersoo L et al. 2020 - Outline of fungi and funguslike taxa. Mycosphere 11, 1060-1456.

Xiao YP, Hongsanan S, Hyde KD, Brooks S et al. 2019 - Two new entomopathogenic species of Ophiocordyceps in Thailand. MycoKeys 47, 53-74.

Zhang K, Adams JM, Shi Y, Yang T et al. 2017 - Environment and geographic distance differ in relative importance for determining fungal community of rhizosphere and bulk soil. Environmental Microbiology 19, 3649-3659.

Zhang ZF, Zhou SY, Eurwilaichitr L, Ingsriswang S et al. 2020 - Culturable mycobiota from Karst caves in China II, with descriptions of 33 new species. Fungal Diversity 106, 29-136. 